\title{
Research on the Relationship Between the Degree of European Corn Borer (Ostrinia Nubilalis Hbn.) Attack and Maize Fusariosis (Fusarium spp.) at ARDS Turda
}

\author{
Ana-Maria VĂLEAN ${ }^{1,2, *}$, Felicia MUREŞANU ${ }^{1}$, Adina TĂRĂU ${ }^{1,2}$, Loredana SUCIU ${ }^{1,2}$, Laura ŞOPTEREAN ${ }^{1,2}$, \\ Ion OLTEAN ${ }^{2}$ \\ ${ }^{1}$ Agricultural Research-Development Station Turda, Str. Agriculturii, Nr. 27 Județul Cluj, România \\ ${ }^{2}$ Faculty of Agriculture, University of Agricultural Sciences and Veterinary Medicine, Str. Mănăștur, Nr. \\ 3-5, 400372, Cluj-Napoca, România \\ *Corresponding author: pacurar.anamaria@yahoo.com
}

Bulletin USAMV series Agriculture 74(1)/2017

Print ISSN 1843-5246; Electronic ISSN 1843-5386

DOI 10.15835/buasvmcn-agr: 12659

\begin{abstract}
The European corn borer (Ostrinia nubilalis Hübn.), which is found almost universally in Europe and America, is an extremely important pest from economic point of view (Szőke et al., 2005). European corn borer larvae cause physical injuries to stalks and ears, and promote infections with Fusarium, by carrying the fungus spores from the plant surface to the surfaces of damaged kernels or to the interior of stalks, where infection occurs (Czembor, 2015). On account of the fact that between Ostrinia nubilalis Hbn. and Fusarium spp. there is a strong connection, and their presence lead to lower maize production, it's purposed is reducing the corn borer attack, but also the occurrence of maize fusariosis, by applying treatments to the vegetation. The research was carried out at ARDS Turda, in the period 2014-2015 as a bifactorial experience, in which were performed two treatments on growing period, with insecticides, using the products: Avaunt $250 \mathrm{ml} / \mathrm{ha}$ (s.a. indoxacarb), Coragen $250 \mathrm{ml} / \mathrm{ha}$ (s.a. chlorantraniliprol), Proteus $400 \mathrm{ml} /$ ha (s.a. tiacloprid + deltametrin), Calypso $150 \mathrm{ml} / \mathrm{ha}$ (s.a. tiacloprid) and Confidor $400 \mathrm{ml} / \mathrm{ha}$ (s.a. imidacloprid + deltametrin), and the biological material was used Turda 165 hybrid. Amid the climatic conditions in the two experimental years (2014-2015), regarding the frecquency attack of the Ostrinia nubilalis, 2015 proved to be a very favorable year for this pest, and by applying treatments to the vegetation, Ostrinia nubilalis Hbn. and Fusarium spp. attack has been reduced very significant. In order to combat the european corn borer (Ostrinia nubilalis $\mathrm{Hbn}$.) chemically, are recommended products based on: chlorantraniliprol and tiacloprid+deltametrin.
\end{abstract}

Keywords: Fusarium spp., maize, Ostrinia nubilalis, treatments

\section{INTRODUCTION}

Maize (Zea mays L.) is an agricultural crop of worldwide importance grown both for the food industry and for other purposes (Nedělník, 2012).

Pests and plant diseases are biotic factors that reduce crop yields, and their presence in agroecosystems can also affect yield quality parameters (Kocmánková, 2010).
Of all maize diseases, fusariosis is the most important one because of its spread in the crop areas and also because of the high-frequency attack, causing the most significant yield losses. It occurs during two distinct periods of the vegetation cycle in maize: from germination to the stage of 3-4 leaves and from flowering to maturity (Nagy, 2004). 
Despite the fact that more than $95 \%$ of the maize seeds planted in Europe every year are treated with fungicides, disease problems continue to develop in many fields affecting both the yield and quality of the grain crop. Fusarium spp. causing ear rots are the most economically significant diseases in most European regions and, with the exception of Spain, are an increasing problem in Europe (Czembor, 2010)

There is often a high correlation between symptoms of pink ear rot and ear damage caused by European corn borer larvae (Ostrinia nubilalis Hbn.). Larvae cause physical injuries to stalks and ears, and promote infections by Fusarium spp. in two ways. Firstly, European corn borer larvae can carry spores of Fusarium species from the plant surface to the surfaces of damaged kernels or to the interior of stalks, where infection occurs. Viable spores can be found externally and internally in European corn borer larvae. Secondly, these larvae form entry wounds when feeding on stalks or kernels. Even when larvae do not directly carry fungi into the stalks, spores subsequently deposited on wounded tissue are very likely to germinate and infect the plant. It should be noted, though, that there is some disagreement among plant pathologists about the overall importance of insect tunneling on stalk rot development (Czembor, 2010).

The European corn borer (Ostrinia nubilalis Hübn.), which is to be found almost universally in Europe and America, is an extremely important pest from the economic point of view. Losses caused by the pest range from $250-1000 \mathrm{~kg} / \mathrm{ha}$ depending on the degree of infestation, the year and the yield averages (Szőke et al., 2005).

Temperature is identified as the dominant abiotic factor directly affecting the insects (Bale et al., 2002). Climate can limit the distribution of a species directly by influencing survival and fecundity, or indirectly through its effects on interacting species, including food sources, natural enemies, and competitors (Gaston, 2003). Changes in climate conditions may therefore result in alterations in the geographical distribution of a species, variability in overwintering and population growth rates, increases in the number of generations, extension of the developmental period, effects on crop-pest synchrony, changes in interspecies interactions, and increased risk of invasion by migrant pests (Porter et al., 1991).

\section{MATHERIAL AND METHOD}

Because of the fact that there is a positive correlation between Ostrinia Nubilalis and Fusarium spp., the effect of the treatments on vegetation against pest attack and implicitly on the indication of corn cob fusariosis has been studied at ARDS Turda, within the Plant Protection Laboratory, during the period 2014-2015.

The emplacement method of the experience has been the randomized block design, with three repeated stages, having 5 variants that have received treatment and 1 variant as control sample, without treatment applied. Each parcel had a length of 5 meters. The biological material used was hybrid Turda 165, created by ARDS Turda. The corn seed has been treated with the product Maxim XL in a ratio of $1 \mathrm{l} / \mathrm{t}$ of seed. For the treatments on vegetation against the corn borer five products have been used: Avaunt $250 \mathrm{ml} / \mathrm{ha}$ (active agent: indoxacarb), Coragen $250 \mathrm{ml} / \mathrm{ha}$ (active agent: chlorantraniliprole), Proteus 400 $\mathrm{ml} /$ ha (active agent: thiacloprid + deltamethrin), Calypso $150 \mathrm{ml} /$ ha (active agent: thiacloprid) and Confidor $400 \mathrm{ml} /$ ha (active agent: imidacloprid + deltamethrin). Two treatments have been administered: the first treatment was applied at the first signs of the pest outbreak, when on the pheromone traps between 5 to 8 adults have been detected, and the second treatment was administered after an interval of 12 days after the first treatment.

Ratings were made concerning the corn borer both on the stem and the cob in the experimental field. Sections have been executed in the corn plants, in order to determine the number of bores/plant, the amount of corn borer larvae and the number of galleries resulting from the attack. As regards the corn cob fusariosis, observations have been made in what regards the attack on the cob and the number of broken plants has been recorded. The yield has been determined in the laboratory, being expressed as q/ha with $85 \%$ d.w.

\section{RESULTS AND DISCUSSION}

Roșca and Rada stated in 2009 that excessive temperatures accompanied by drought during the egg-laying period causes a low fertility and a low percentage of hatching of larvae, while rains and high winds during the same period determine the death of larvae that are in early stages of development, before they penetrate the plant. 


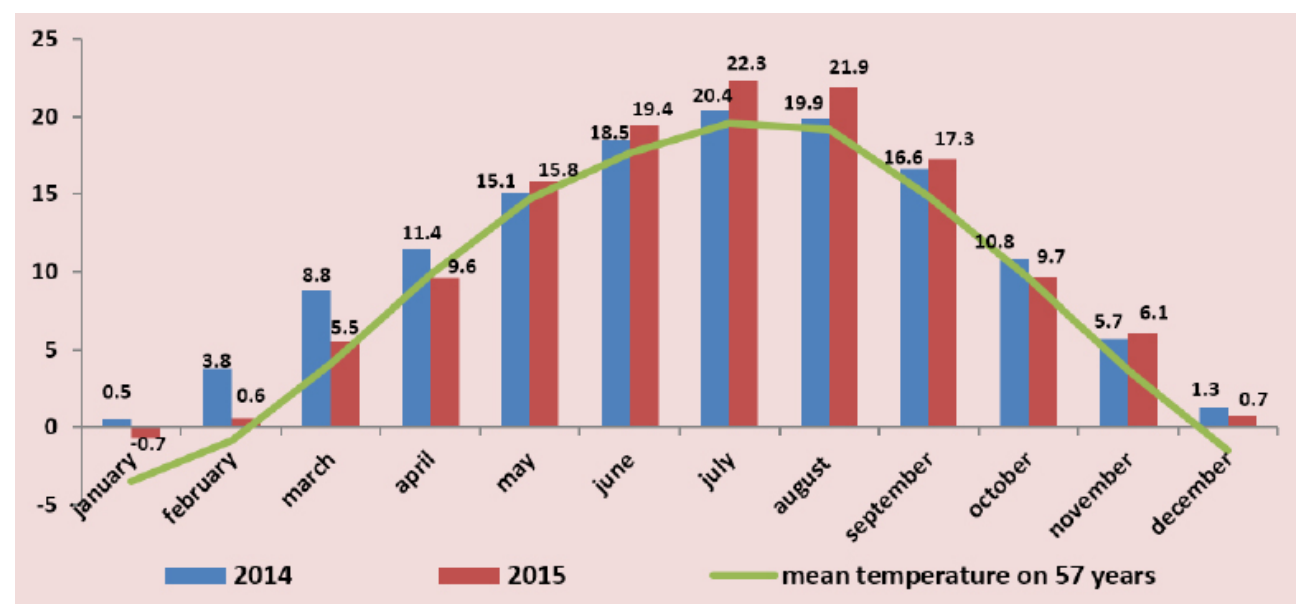

Fig. 1. Thermal conditions at ARDS Turda, $2014-2015$

(Source: The meteorological station Turda (longitude: $23^{\circ} 47^{\prime}$; latitude $46^{\circ} 35^{\prime}$; altitude $427 \mathrm{~m}$ )

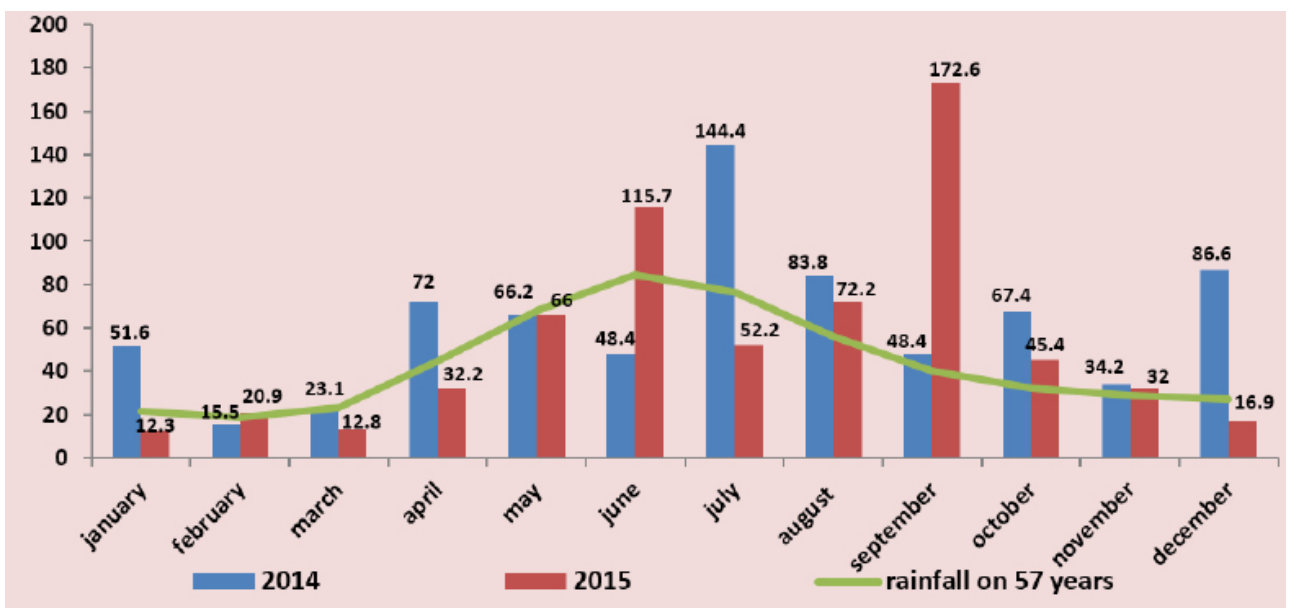

Fig. 2. Rainfall at ARDS Turda, 2014 - 2015

(Source: The meteorological station Turda (longitude: $23^{\circ} 47^{\prime}$; latitude $46^{\circ} 35^{\prime}$; altitude $427 \mathrm{~m}$ )

The climatic conditions are very important in the evolution and development of the pest, especially during the months of June and July, period during which the eggs hatch, and the larvae begin to attack the corn plants. On Fig. 1, it can be seen that during the two years of the experiment which have been taken into account within the study, the average temperatures during the months of June and July were higher than the multi-annual average. In 2014 the average monthly temperature was higher by $+2.1^{\circ} \mathrm{C}$ compared to the average, and in 2015 the difference was even greater, of $+2.7^{\circ} \mathrm{C}$. The months of June and July were considered normal for the year 2014, as opposed to the year 2015 , as they have been characterized as warm months. In what regards the temperature in both years of the experiment, it can be stated that both years used to be favorable to the development of the pest and to the evolution of the attack.

In terms of precipitation, 2014 had 5 excessively rainy months. If June was characterized as very dry, July instead was excessively rainy with a deviation from the annual average of $67.7 \mathrm{~mm}$. The month of June 2015 instead was very rainy and in July drought had stepped in. This led the corn plants to suffer, because of the lack of water when it was essential, during the vegetation season, and for this reason year 2014 was a more beneficial year for maize.

During the two years of the experiment, the attack of Ostrinia nubilalis has been recorded for all the experimental variants. By making a comparison of the two years, it can be perceived that during 2015 the incidence of the corn borer 
Tab. 1. Frequency of Ostrinia nubilalis Hbn. attack on stem ( $\arcsin \sqrt{\%})$

\begin{tabular}{|c|c|c|c|c|c|c|}
\hline Year & Variant & $\begin{array}{c}\text { Frequency } \\
\text { attack on stem }\end{array}$ & $\begin{array}{c}\% \text { to } \\
\text { control }\end{array}$ & $\begin{array}{c}\text { The difference } \\
\text { to control }\end{array}$ & $\begin{array}{l}\text { The significance } \\
\text { of the difference }\end{array}$ & $\begin{array}{c}\text { Duncan } \\
\text { Test }\end{array}$ \\
\hline \multirow{6}{*}{2014} & Mt. netratat & 60.76 & 100.0 & 0.00 & Mt. & $\mathrm{G}$ \\
\hline & Avaunt $250 \mathrm{ml} / \mathrm{ha}$ & 22.94 & 37.8 & -37.82 & 000 & $\mathrm{~B}$ \\
\hline & Coragen $250 \mathrm{ml} / \mathrm{ha}$ & 12.15 & 20.0 & -48.62 & 000 & $\mathrm{~A}$ \\
\hline & Proteus $400 \mathrm{ml} / \mathrm{ha}$ & 25.03 & 41.2 & -35.74 & 000 & $\mathrm{~B}$ \\
\hline & Calypso $150 \mathrm{ml} / \mathrm{ha}$ & 48.54 & 79.9 & -12.22 & 000 & $\mathrm{E}$ \\
\hline & Confidor $400 \mathrm{ml} / \mathrm{ha}$ & 39.79 & 65.5 & -20.97 & 000 & $\mathrm{D}$ \\
\hline \multirow{6}{*}{2015} & Mt. netratat & 81.88 & 100.0 & 0.00 & Mt. & $\mathrm{I}$ \\
\hline & Avaunt $250 \mathrm{ml} / \mathrm{ha}$ & 54.78 & 66.9 & -27.10 & 000 & $\mathrm{~F}$ \\
\hline & Coragen $250 \mathrm{ml} / \mathrm{ha}$ & 31.43 & 38.4 & -50.45 & 000 & $\mathrm{C}$ \\
\hline & Proteus $400 \mathrm{ml} / \mathrm{ha}$ & 48.32 & 59.0 & -33.56 & 000 & $\mathrm{E}$ \\
\hline & Calypso $150 \mathrm{ml} / \mathrm{ha}$ & 70.30 & 85.9 & -11.58 & 000 & $\mathrm{H}$ \\
\hline & Confidor $400 \mathrm{ml} / \mathrm{ha}$ & 62.87 & 76.8 & -19.01 & 000 & $\mathrm{G}$ \\
\hline $\begin{array}{l}\text { LSD (p 5\%) } \\
\text { LSD (p 1\%) } \\
\text { LSD (p 0.1\%) }\end{array}$ & & $\begin{array}{l}5.28 \\
7.18 \\
9.74\end{array}$ & & & & \\
\hline
\end{tabular}

Tab. 2. Frequency of broken plants at Turda 165 hybrid (ARDS TURDA, 2014-2015)

\begin{tabular}{|c|c|c|c|c|c|}
\hline Year & Variant & $\begin{array}{c}\text { Broken } \\
\text { plants } \\
(\%)\end{array}$ & $\begin{array}{c}\% \text { to } \\
\text { control }\end{array}$ & $\begin{array}{c}\text { The difference } \\
\text { to control }\end{array}$ & $\begin{array}{c}\text { The significance of } \\
\text { the difference }\end{array}$ \\
\hline \multirow{6}{*}{2014} & Mt. netratat & 7.40 & 100.0 & 0.00 & Mt. \\
\hline & Avaunt $250 \mathrm{ml} / \mathrm{ha}$ & 0.0 & 0.1 & -15.79 & 000 \\
\hline & Coragen $250 \mathrm{ml} / \mathrm{ha}$ & 0.0 & 0.1 & -15.79 & 000 \\
\hline & Proteus $400 \mathrm{ml} / \mathrm{ha}$ & 3.13 & 64.5 & -5.61 & 000 \\
\hline & Calypso $150 \mathrm{ml} / \mathrm{ha}$ & 7.73 & 102.9 & 0.46 & - \\
\hline & Confidor $400 \mathrm{ml} / \mathrm{ha}$ & 6.07 & 89.4 & -1.68 & - \\
\hline \multirow{6}{*}{2015} & Mt. netratat & 8.77 & 100.0 & 0.00 & Mt. \\
\hline & Avaunt $250 \mathrm{ml} / \mathrm{ha}$ & 2.43 & 52.2 & -8.22 & 000 \\
\hline & Coragen $250 \mathrm{ml} / \mathrm{ha}$ & 0.0 & 0.1 & -17.18 & 000 \\
\hline & Proteus $400 \mathrm{ml} / \mathrm{ha}$ & 4.00 & 66.4 & -5.78 & 000 \\
\hline & Calypso $150 \mathrm{ml} / \mathrm{ha}$ & 6.53 & 85.7 & -2.45 & - \\
\hline & Confidor $400 \mathrm{ml} / \mathrm{ha}$ & 6.33 & 84.5 & -2.67 & - \\
\hline $\begin{array}{l}\text { LSD (p 5\%) } \\
\text { LSD (p 1\%) } \\
\text { LSD (p 0.1\%) }\end{array}$ & & & & & \\
\hline
\end{tabular}

was greater, the year being more favorable to this vermin. With regard to the experimental variants, it can be seen that for all the variants to which treatment has been applied, the rate of attack on vegetation, was less significant, with a very relevant negative difference compared to the witness crop. The experiment variants for which Coragen has been applied stand out (in both years of the experiment), having the lowest rate of attack (12.15\% and $31.43 \%$ respectively).
The percentage of broken plants was low in both years of the experiment. The variants on which the Avaunt, Coragen and Proteus products have been administered have shown noticeable negative differences relatively to the untreated witness crop. Within the variant treated with Coragen, no broken plants have been recorded $(0.00 \%)$, aspect which correlates positively with the lowest rate of Ostrinia nubilalis attack on this variant (Tab.2). 


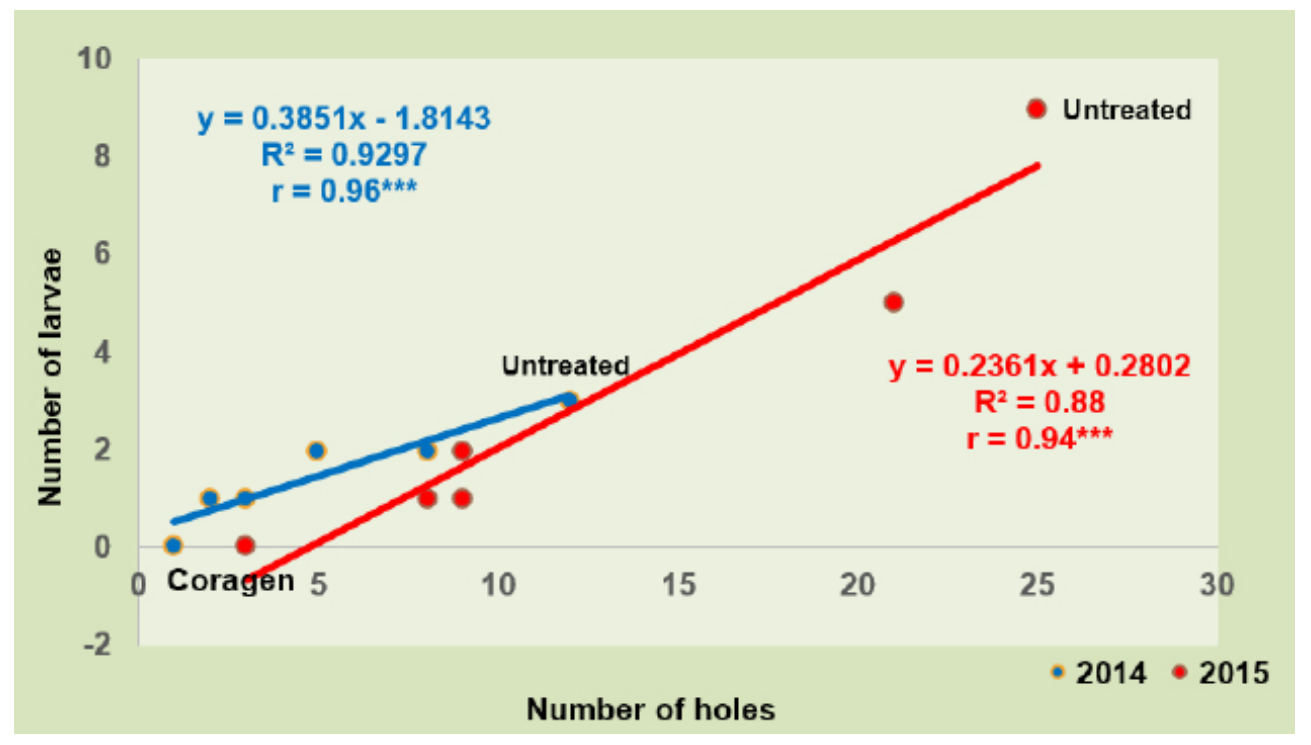

Fig. 3. Relationship between the number of larvae and number of holes produced by Ostrinia nubilalis Hbn. at Turda 165 hybrid

Tab. 3. Frequency of Ostrinia nubilalis Hbn. attack on $\operatorname{cob}(\arcsin \sqrt{ } \%)$

\begin{tabular}{|c|c|c|c|c|c|c|}
\hline Year & Variant & $\begin{array}{c}\text { Frequency attack } \\
\text { on cob } \\
\end{array}$ & $\begin{array}{c}\% \text { to } \\
\text { control } \\
\end{array}$ & $\begin{array}{c}\text { The difference } \\
\text { to control }\end{array}$ & $\begin{array}{l}\text { The significance } \\
\text { of the difference }\end{array}$ & Duncan Test \\
\hline \multirow{6}{*}{2014} & Mt. netratat & 25.74 & 100.0 & 0.00 & Mt. & $\mathrm{E}$ \\
\hline & Avaunt $250 \mathrm{ml} / \mathrm{ha}$ & 19.37 & 75.2 & -6.37 & 000 & $\mathrm{BC}$ \\
\hline & Coragen $250 \mathrm{ml} / \mathrm{ha}$ & 14.81 & 57.5 & -10.93 & 000 & A \\
\hline & Proteus $400 \mathrm{ml} / \mathrm{ha}$ & 20.70 & 80.4 & -5.04 & 000 & $\mathrm{CD}$ \\
\hline & Calypso $150 \mathrm{ml} / \mathrm{ha}$ & 21.72 & 84.4 & -4.02 & 000 & $\mathrm{D}$ \\
\hline & Confidor $400 \mathrm{ml} / \mathrm{ha}$ & 21.25 & 82.5 & -4.50 & 000 & $\mathrm{D}$ \\
\hline \multirow{6}{*}{2015} & Mt. netratat & 54.58 & 100.0 & 0.00 & Mt. & I \\
\hline & Avaunt $250 \mathrm{ml} / \mathrm{ha}$ & 24.40 & 44.7 & -30.18 & 000 & $\mathrm{E}$ \\
\hline & Coragen $250 \mathrm{ml} / \mathrm{ha}$ & 19.12 & 35.0 & -35.46 & 000 & $\mathrm{~B}$ \\
\hline & Proteus $400 \mathrm{ml} / \mathrm{ha}$ & 31.84 & 58.3 & -22.74 & 000 & $\mathrm{~F}$ \\
\hline & Calypso $150 \mathrm{ml} / \mathrm{ha}$ & 51.42 & 94.2 & -3.16 & 000 & $\mathrm{H}$ \\
\hline & Confidor $400 \mathrm{ml} / \mathrm{ha}$ & 44.25 & 81.1 & -10.32 & 000 & $\mathrm{G}$ \\
\hline $\begin{array}{l}\text { SD (p 5\% } \\
\text { SD (p 1\% } \\
\text { SD ( p 0.1 }\end{array}$ & & $\begin{array}{l}1.38 \\
1.88 \\
2.55\end{array}$ & & & & \\
\hline
\end{tabular}

There is a direct and very significant relationship between number of larvae and the number of holes on the plants. The influence of the environmental conditions in the manifestation of Ostrinia nubilalis attack can also be seen from this relationship, reflected in the length of the regression line regarding the two years of the experiment. A close link between the two variables is also highlighted by the values of the coefficient of determination, such that in approximately $90 \%$ of cases, the increase of the number of larvae results in an increase in the number of holes (Fig. 3).

In respect to the attack of Ostrinia nubilalis on the cob, the highest rate of attack rate has been recorded on the control crop. Compared to this, the variants on which treatments have been applied over the vegetation, the attack rate of the vermin was more reduced, having statistically significant negative differences in both years of the experiment. In these circumstances it can be 
Tab. 4. The Fusarium spp degree of. attack on ears $(\arcsin \sqrt{ } \%)$

\begin{tabular}{|c|c|c|c|c|c|c|}
\hline Year & Variant & $\begin{array}{c}\text { The degree } \\
\text { attack }\end{array}$ & $\begin{array}{c}\% \text { to } \\
\text { control } \\
\end{array}$ & $\begin{array}{c}\text { The difference } \\
\text { to control }\end{array}$ & $\begin{array}{l}\text { The significance } \\
\text { of the difference }\end{array}$ & Duncan Test \\
\hline \multirow{6}{*}{2014} & Mt. netratat & 3.15 & 100.0 & 0.00 & Mt. & $\mathrm{E}$ \\
\hline & Avaunt $250 \mathrm{ml} / \mathrm{ha}$ & 1.62 & 51.4 & -1.53 & 000 & $\mathrm{~B}$ \\
\hline & Coragen $250 \mathrm{ml} / \mathrm{ha}$ & 1.28 & 40.5 & -1.88 & 000 & $\mathrm{~A}$ \\
\hline & Proteus $400 \mathrm{ml} / \mathrm{ha}$ & 2.11 & 66.8 & -1.05 & 000 & $\mathrm{C}$ \\
\hline & Calypso $150 \mathrm{ml} / \mathrm{ha}$ & 2.77 & 87.8 & -0.38 & 0 & $\mathrm{D}$ \\
\hline & Confidor $400 \mathrm{ml} / \mathrm{ha}$ & 2.38 & 75.4 & -0.78 & 000 & $\mathrm{C}$ \\
\hline \multirow{6}{*}{2015} & Mt. netratat & 7.27 & 100.0 & 0.00 & Mt. & I \\
\hline & Avaunt $250 \mathrm{ml} / \mathrm{ha}$ & 3.08 & 42.3 & -4.19 & 000 & $\mathrm{DE}$ \\
\hline & Coragen $250 \mathrm{ml} / \mathrm{ha}$ & 2.22 & 30.5 & -5.05 & 000 & $\mathrm{C}$ \\
\hline & Proteus $400 \mathrm{ml} / \mathrm{ha}$ & 4.17 & 57.4 & -3.10 & 000 & $\mathrm{~F}$ \\
\hline & Calypso $150 \mathrm{ml} / \mathrm{ha}$ & 6.79 & 93.4 & -0.48 & 00 & $\mathrm{H}$ \\
\hline & Confidor $400 \mathrm{ml} / \mathrm{ha}$ & 6.11 & 84.0 & -1.16 & 000 & $\mathrm{G}$ \\
\hline $\begin{array}{l}\text { LSD (p 5\%) } \\
\text { LSD (p 1\%) } \\
\text { LSD (p 0.1\%) }\end{array}$ & & $\begin{array}{l}0.33 \\
0.45 \\
0.61\end{array}$ & & & & \\
\hline
\end{tabular}

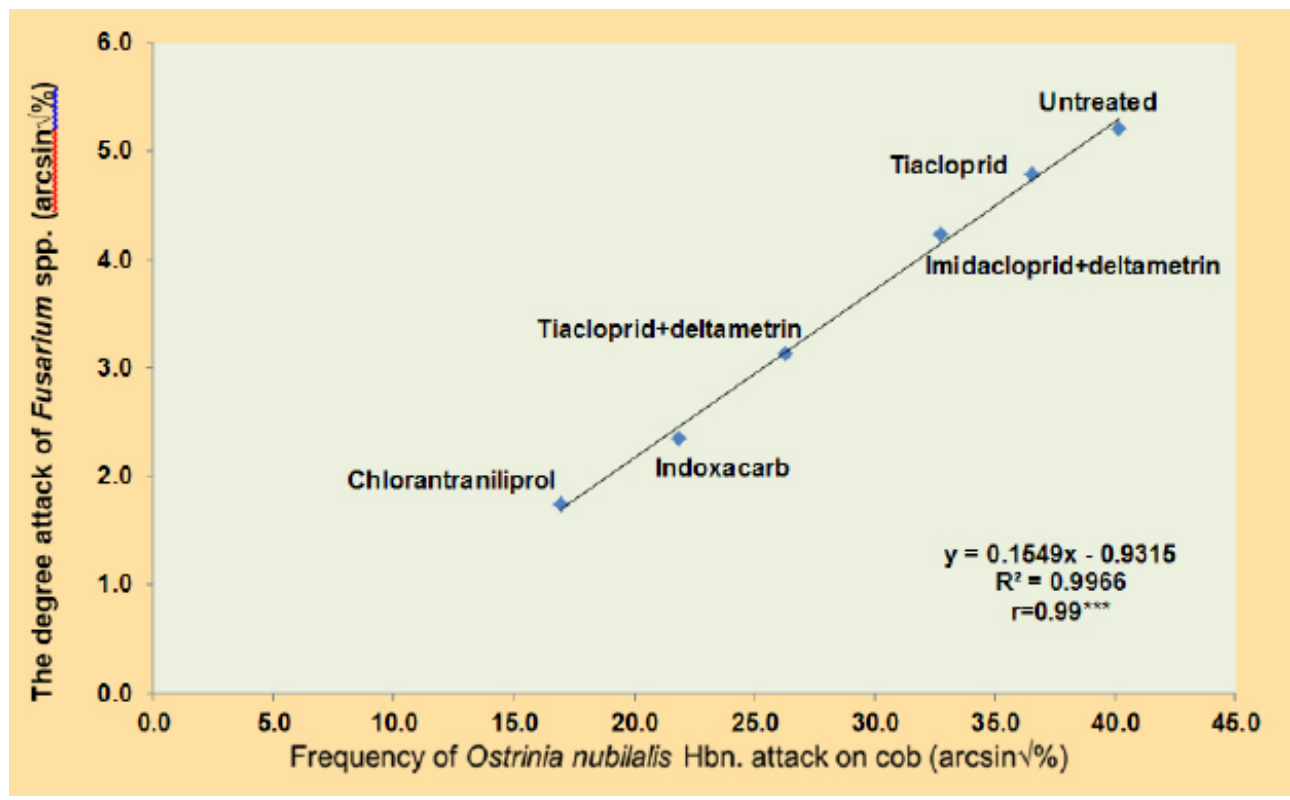

Fig. 4. The correlation between frequency attack of Ostrinia nubilalis and the degree attack of Fusarium spp. on ears

stated that all products have had efficacy against the vermin. In both years of the experiment, the variant that has been treated with Coragen is to be noticed, as it yielded the lowest recorded values of the attack, aspect that was been also confirmed trough the classification resulting from the Duncan multiple range test (tab. 3).

Due to the fact that there are pathogenic relations between Ostrinia nubilalis and the fungi of the genus Fusarium, observations have been also conducted regarding the corn cob fusariosis. The administration of the products for the control of the corn borer, has led to its control, and this effect was also in conjunction with a much lower degree of attack by Fusarium spp. The attack on the cob was much weaker in comparison with the control group. For the variant that resulted in the lowest rate of Ostrinia nubilalis attack (14.81\%) 
Tab. 5. The effect on vegetation treatments on yield (q/ha)

\begin{tabular}{|c|c|c|c|c|c|c|}
\hline Year & Variant & Yield (q/ha) & $\begin{array}{c}\% \text { to } \\
\text { control }\end{array}$ & $\begin{array}{c}\text { The } \\
\text { difference to } \\
\text { control }\end{array}$ & $\begin{array}{l}\text { The significance } \\
\text { of the difference }\end{array}$ & $\begin{array}{c}\text { Duncan } \\
\text { Test }\end{array}$ \\
\hline \multirow{6}{*}{2014} & Mt. netratat & 99.61 & 100.0 & 0.00 & Mt. & $\mathrm{AB}$ \\
\hline & Avaunt $250 \mathrm{ml} / \mathrm{ha}$ & 113.16 & 113.6 & 13.56 & $*$ & $\mathrm{AB}$ \\
\hline & Coragen $250 \mathrm{ml} / \mathrm{ha}$ & 120.23 & 120.7 & 20.62 & $* * *$ & A \\
\hline & Proteus $400 \mathrm{ml} / \mathrm{ha}$ & 106.05 & 106.5 & 6.45 & - & $\mathrm{AB}$ \\
\hline & Calypso $150 \mathrm{ml} / \mathrm{ha}$ & 99.29 & 99.7 & -0.32 & - & $\mathrm{BC}$ \\
\hline & Confidor $400 \mathrm{ml} / \mathrm{ha}$ & 102.27 & 102.7 & 2.66 & - & $\mathrm{AB}$ \\
\hline \multirow{6}{*}{2015} & Mt. netratat & 76.70 & 100.0 & 0.00 & Mt. & $\mathrm{F}$ \\
\hline & Avaunt $250 \mathrm{ml} / \mathrm{ha}$ & 87.57 & 114.2 & 10.87 & - & $\mathrm{CD}$ \\
\hline & Coragen $250 \mathrm{ml} / \mathrm{ha}$ & 91.21 & 118.9 & 14.51 & $*$ & $\mathrm{CD}$ \\
\hline & Proteus $400 \mathrm{ml} / \mathrm{ha}$ & 86.13 & 112.3 & 9.43 & - & DE \\
\hline & Calypso $150 \mathrm{ml} / \mathrm{ha}$ & 85.41 & 111.3 & 8.70 & - & $\mathrm{EF}$ \\
\hline & Confidor $400 \mathrm{ml} / \mathrm{ha}$ & 86.51 & 112.8 & 9.81 & - & $\mathrm{CDE}$ \\
\hline $\begin{array}{l}\text { LSD (p 5\%) } \\
\text { LSD (p 1\%) } \\
\text { LSD (p 0.1\%) }\end{array}$ & & $\begin{array}{l}11.10 \\
15.08 \\
20.44\end{array}$ & & & & \\
\hline
\end{tabular}

(tab. 4), the lowest degree of fusariosis attack (1.28\%) was also recorded.

The close relationship of Ostrinia nubilalis with the fungi of the genus Fusarium can also be seen in Fig. 4. The values of the coefficient of determination indicate that in about $99 \%$ of the cases, the attack rate of the corn borer results in the increase of the attack rate of Fusarium spp.

The production of maize can be greatly diminished due to the presence of the corn borer and by the presence of pathogens that settle on the corn cob because of this vector. As it was to be expected, the treatments administered on the vegetation had no effect on the pest and inferentially on yield. Due to the fact that 2014 was a favorable year for maize, it can be noted that the yields were higher compared to the year 2014. The administration of the treatments on vegetation has led to increases in production between 2.66 and $20.62 \mathrm{q} / \mathrm{ha}$, compared to the witness variant, aspect which correlated positively with a lower attack rate of the corn borer on these variants. According to the Duncan multiple range test classification, the variant over which Coragen has been administered, in year 2014 Coragen, has obtained the largest production (120.23 q/ha) (tab. 5).

\section{CONCLUSIONS}

The fight against the pest is based mostly on preventive measures: prevention of the monoculture; implementation of the right agrotechnology; the use of hybrids with tolerance to this harmful organism;

From the two aforementioned years of the experiment, year 2015 has proved to be a very favorable year for the onslaught of Ostrinia nubilalis.

In order to combat the corn borer (Ostrinia nubilalis Hbn.) by chemical means, the recommended products are based on: chlorantraniliprole and thiacloprid + deltamethrin.

By applying treatments on vegetation, the attack of Ostrinia nubilalis is significantly reduced, and in these circumstances, this correlates positively also with the reduced attack of Fusarium spp.

\section{REFERENCES}

1. Bale JS (2002). Herbivory in global climate change research: direct effects of rising temperature on insect herbivores, Global Change Biology, Volume 8, Pages 1-16

2. Czembor E (2010). Prevention Of Ear Rots Due To Fusarium Spp. On Maize And Mycotoxin Accumulation , ENDURE Maize Case Study - Guide Number 3;

3. Gaston KJ (2003). The Structure and Dynamics of Geographical Ranges, Oxford University Press, Oxford; 
4. Kocmánková E, Trnka M, Eitzinger J, Formayer $\mathrm{H}$, Dubrovsk M, Semerádová D, Salud Z, Juroch J, Mozny M (2010). Estimating the impact of climate change on the occurrence of selected pests in the Central European region, Climate Research, Vol. 44: 95-105;

5. Nagy E (2004). Bolile porumbului în lucrarea PorumbulStudiul monografic, Editura Academiei Române, București, pag. 548-588;

6. Nedělník J, Lindušková $H, K$ Kmoch M (2012). Influence of Growing Bt maize on Fusarium Infection and Mycotoxins
Content - a Review, Vol. 48, Special Issue: S18-S24, Plant Protect. Sci;

7. Porter JH, Parry ML, Carter TR (1991). The potential effects of climatic change on agricultural insect pests. Agric For Meteorol 57:221-240;

8. Szőke C, Zsubori Z, Pók I, Rácz E, Illés O, Szegedi I (2002). Significance of the European corn borer (Ostrinia nubilalis $H u ̈ b n$.) in maize production, Acta Agronomica Hungarica, 50(4): 447-461. 